\title{
Narrative methods in the nursery: (re)- considering claims to give voice through processes of decision-making.
}

\section{Jayne Osgood London Metropolitan University}

\begin{abstract}
From a feminist post-structuralist position I recount and reflect upon using narrative methods in a recent study with a sample of nursery workers in London. Firstly, I offer a critical reflection of feminist concerns to undertake research in emancipatory and recipricol ways. The decision-making that took place at various stages of the study is explored to consider the tensions and ambiguities that come to characterise feminist post-structuralist approaches to narrative research. The paper concludes by arguing that there is still an important need to hear the stories of marginalised groups. However, to overcome concerns that 'giving voice' is unethical, arrogant, and partial then heightened transparency about decisionmaking and representation is vital.
\end{abstract}

\section{Introduction: a politically motivated study}

The research drawn upon in this paper was motivated by feminist ambitions. It was my aim to critically engage with the lived experiences of nursery workers at a key policy moment. The professionalization agenda in early childhood education and care (ECEC) (in the UK) was attracting much attention at the time the research was undertaken (2003-2008). Whilst there was much debate through a range of discourses (political, media, public) the voices of the women that make up the workforce were significant by their absence. It was my intention that space should be made available for alternative discursive constructions to emerge from this occupational group by using narrative methods of qualitative enquiry.

Smith (1993) argues that narratives enable access to an individual's subjectivity, experience and reflections of the past and for that reason they have been attractive to feminist researchers wishing to explore the experiences of women hidden from history as well as a means of accessing women's voices. Narrative methods have been celebrated for the opportunities they offer to make space for formerly silenced or marginalized voices and for their emancipatory potential. At the outset of the research I was particularly seduced by such promises. However, as the research process unfolded I became acutely troubled by the naivety of such claims. The notion of 'giving voice' to marginalized groups through narrative methods has long been the focus of debate and has most recently been taken up by Mazzei \& Jackson (2009) who identify a:

'drive to make voices heard and understood, bringing meaning and self to consciousness and creating transcendental, universal truths [which] gestures towards the primacy of voice in conventional qualitative research' (2009:1).

The ethics of representing the voices of others through qualitative research has been questioned and critiqued on the grounds of the privileging that occurs in the decisions that are made and the ways in which participant voices are portrayed and presented (Guba \& Lincoln, 2005; Lather 2007). Furthermore, Mazzei and Jackson are unconvinced that feminist attempts to equalise and democratise the research process make the decision-making involved in 'giving voice' in anyway transparent. Yet, since feminist scholarship has a liberatory agenda female scholars are necessarily required to speak on behalf of other 
women (across differences of race, culture, sexuality and power) despite the associated problems, seeming arrogance and ethical dilemmas it presents (Alcoff, 2009).

Through this paper I endeavour to make transparent some of the decision-making that took place throughout the course of my research with a group of marginalized women. I attempt to present a research story that illustrates the significance of power in research encounters and relationships. I engage with post-structuralist debate that 'voices heard' are only ever partial, interpreted, reframed, and presented with certain (feminist) aims in mind. As such, when research is conducted in a transparent and reflexive way it might avoid the criticism that it claims to represent universal truths about participant groups. As Blumenreich (2004:79) usefully states:

'Post structural narratives resist the conventional "resolution" of standard narratives that stabilises meaning and implicitly favours a single interpretation'.

Therefore whilst narrative techniques might be aligned to feminist politics they should only be cautiously adopted for the potential they offer to 'hear stories'. This paper offers reflections on how various stages of the research process must be carefully negotiated. Working within a post-structuralist framework reminds the researcher to consider shifting identities (of both researched and researcher), their own actions and thinking as a researcher and to be alert to the contradictions, tensions and ambiguities (Gray, 2007).

\section{Researcher subjectivity}

To claim the study was politically motivated and that my feminist politics were the motivation for the research requires further explanation. Reay (1997:18) considers the ways in which 'the influences of the past and the present are interwoven but also the myriad ways in which they clash and collide'. Such clashes and collisions are vital to developing understandings of the self and offering an account of oneself (Butler, 2005). To locate the impetus for the study reported here I offer a brief insight into the clashes and collisions in my life. Starting with my working-class childhood, which was characterised by traditional conjugal roles within the family. I became acutely aware of my classed position at a young age on account of my father's occupation (farm labourer). The rural working-class community of my childhood was characterised by heterogeneity and discord, which was masked by a duality of landed-gentry and its staff, the 'have-lots' ruling over the 'have-nots'. Despite a romanticised construction of 'contented man of the soil' my father was angry. As I grew older I understood this anger to stem from frustration at his classed oppression, which played out as regular and ugly acts of domestic violence.

Through the study of sociology, and in particular Marxist theory, I was provided with further plausible classed explanations for the violence at home. As a teenage girl my gendered identity emerged as equally significant to my classed positioning. Marxist explanations of classed oppression denied space to explain what the women in my family experienced at the hands of oppressed men. Other key events in my young adulthood make up a storied narrative of my life which I consider to have significant bearing on how I make sense of myself and my political motivations. These include the tumultuous process of 'coming out' as a working-class lesbian that my sister endured; my unexpected academic success at school, my resistance to the classed expectations set before me by family (marriage, motherhood, life in the domestic sphere) and by teachers (a career in childcare). My political conscience developed within a particular socio-political climate. The Thatcher era of the 1980 s in the UK bred a culture of competitive individualism, where social mobility was promoted and failure to thrive attributed to the individual (Hey, 1997). Yet I was aware of the counter discourses and political movements but lacked the means to access them. Our 
family home was very close to RAF Greenham Common (which became a site of mass female protest at nuclear weapons and war) yet I had neither the cultural capital nor the political conscience at that stage to ingratiate myself to this political movement. My shifting class position (through educational success and a heightened political conscience) was both liberatory and terrifying. As many feminist commentators have noted the processes of identification and disidentifcation that accompany social mobility are profound and leave a persistent sense of dislocation (Hey 1997; Hughes, 2004; Reay, 1996; Walkerdine, 1990).

The silencing and containment of working-class women's oppression, marginalisation and powerlessness provided my motivation to resist normalised expectations. In drawing upon Foucauldian notions of 'an ethics of the self', McNay (1994) advocates a reflexive examination of the process of subjection; the processes through which individuals come to understand themselves as subjects. She argues that an ethics of the self is not based on an adherence to externally opposed moral obligations, but rather on an ethics of who we are said to be, and therefore what is its possible for us to become. It is not about a true essence, there is no self waiting to be discovered, but rather a process of creation and reinvention out of available resources. A brief narration of my life demonstrates processes of subjection; the various investments and rejections of particular discourses at different points. Although how I come to understand myself constantly shifts what has remained is a commitment to understand and challenge the structural injustices that working-class women encounter through normalising middle-class discourses and discursive practices (Reay, 1996).

Beyond a degree of empathy with nursery workers (as principally young working-class women fulfilling a classed and gendered trope) I was committed to conducting this study so that counter discourses, from within the profession, could be heard. I rejected a career in childcare and instead opted for a studious career trajectory into academia. Yet my brief encounters working with children coupled with the classed expectations and experiences of my childhood provided an impetus to want to investigate the lives of women who are engaged in the care and education of other people's children. That desire was furthered by experiences of conducting government funded studies into various aspects of the early years workforce in England from the late 1990s - which were in many ways class and gender blind (eg; Osgood \& Sharp, 2000). The structural inequalities experienced by this occupational group are mirrored in the lack of symbolic value attached to the work that they undertake, and hence their public image and status. As deftly illustrated by Skeggs (1997) and more recently by Colley (2006) working-class women working in caring occupations experience two-fold oppression. It seemed imperative that the voices of this group of marginalized women should be heard at this particular (political) moment. Or as Reay (1997:21) urges: 'Perhaps the once working-class, feminist academic can utilise her working-class experience as a resource in developing theorisations which recognise the complicated emotional and psychological selfhood of working-class people and the material struggles that make up their everyday lives'.

It was, and remains, my belief that research offers women an opportunity to speak out on topics of direct concern (their occupation, the conditions under which they work, the policies that shape the nature of their work) and to offer alternative constructions that can then be heard through authoritative discourse. I wanted to allow space within the research for the personal aspects of life to emerge and to chart their significance to the public constructions of 'the [professional] nursery worker'. In effect I wanted to gain understandings of the personal as professional. I idealistically held the belief that 'giving voice' through hearing the stories of a sample of nursery workers could provide enormous 
emancipatory potential - a view widely shared by a number of participants and offered as their reason to engage with it. But as Gray (2007:428) warns:

'Voice is not simply the story told. Reflecting on the interplay of time, place and space of both the telling and hearing of the narrative, voice is very complex and always political. And since voice is grounded in social contexts, the effects of its articulation, course and reception are intricate and infinite.... whether voice is heard as a compelling proposal, co-opted to support dominant discourse or dismissed as insignificant depends on who says it, and how and where it is said'.

With these caveats and considerations in mind I set about planning and designing the study so that participants would feel able to speak openly and comprehensively about themselves and the multiple identities that they occupy. I agonised about claims to 'give voice' but continued to hold dear the belief that a reflexive and reflective approach to all stages would go some way to ensure the feminist goal of emancipatory research could be at least partially maintained.

\section{Theoretical framing}

The account offered above signals the feminist motivations behind the research that are informed by processes of subjection. However it remains important to locate this study theoretically. The study was broadly undertaken to better understand how nursery worker identities are formed, challenged, (re)negotiated, valued and denigrated. The means by which I undertook this exercise was through a post-structuralist re-reading and problematisation of hegemonic discourses that construct nursery workers in particular ways to satisfy societal and political goals (Foucault, 1980, 1983, 1994; Cannella 1997). I was not concerned to identify an authentic truth, since post-structuralism denies the existence of a single, knowable truth but rather a realm of possibilities dependent upon the subject position of the researcher and the social context in which the research is conducted (Davies, 2000). Therefore the aim of this politically motivated study is to privilege certain discursive truths over others; to achieve emancipatory goals by offering insights into the lives of nursery workers.

The theoretical position adopted emphasises the social construction of knowledge and the rejection of essentialist understandings and realist theorisations of social life (Parker, 1998). Within the research I explore the power at play through critical discourse analyses of narrative; I expose the subjective reading I make and how this relates to specificities of time, space, culture. My concern is to deconstruct and dismantle (Derrida, 1972; Barthes, 1990). Foucault urges problematisation and presentation of alternative readings and the unearthing of whose interests are served through the creation and sustenance of hegemonic discourses (Foucault, 1979). Through processes of dismantling, unsettling and problematizing dominant constructions of what it means to be a woman engaged in work with children, I contend that potential exists for 'the nursery worker' to be constructed in alternate ways. The convergences of feminism(s) and Foucault were influential in framing the study. Whilst the tensions between Foucauldian and post-structuralist feminist theory are well rehearsed (Francis 2001; Ramazanoglu 1994; Tamboukou \& Ball 2003) I draw attention to the uniting aspects as summarised by Diamond \& Quinby (1988). The authors claim that both theoretically focus upon identification of the body as a site of power, through which docility is accomplished and subjectivity constituted; local and intimate operations of power rather than an exclusive focus on the supreme power of the state; the crucial role of discourse in its capacity to produce and sustain hegemonic power and emphasise the challenges contained within marginalized discourses; and criticism of the ways in which western humanism has privileged the experience of the masculine elite as it 
proclaims essentialized claims to truth, freedom and human nature. Using this framework allowed me to identify discourse and to seek out inter-relationships between discourses as well as silences/absences, resistances and counter discourses. By problematizing and unsettling taken for granted assumptions and exposing the effects of power through discourse opportunities to understand 'the nursery worker' in other ways were created. This theoretical framework with its inherent emancipatory goal (to make space for alternative discourses to emerge) underpinned each stage of the research.

The remainder of this paper uses several practical examples to illustrate the dilemmas encountered when endeavouring to undertake research from a post-structural feminist position. I reflect on the tensions and anxieties that emerged at key decision-making moments (recruiting research participants, trying to engage reluctant interviewees, how to manage expectations and consequences of narrative methods). Through these illustrations I attempt to make transparent and expose the messiness of undertaking this type of research. Despite the problems, challenges and limitations associated with 'giving voice' I argue that it remains an important goal for feminist researchers.

\section{Identifying a sample: the place of empathy in feminist research}

The study involved staff in three central London nurseries. I visited each nursery in advance of the fieldwork and made all staff aware of the aims of the study and the nature of their involvement. All 24 members of staff volunteered to participate in a range of data collection but most notable to this paper is the life history interview I undertook with each. The profile of the sample was diverse in terms of age (17-51 years old), occupational position (manager through to parent volunteer), parental status and ethnicity. Unsurprisingly, the classed and gendered composition of the sample reflected the broader workforce with only one male participant and most people identifying as working-class.

Taking into consideration my commitment to 'give voice' set against growing concerns made by commentators such as Arnot \& Reay (2007), Lather (2009), Mazzei \& Jackson (2009), that notions of voice must be complicated and the limitations recognised, I wrestled with the significance of my subjectivity and the multiple (shifting) identities that I occupy and the implications of this for the research. My multiple identities have an inevitable bearing on the approach I take to research. The shifts in certain identities that I occupy (eg class, maternity, age, occupation) and the static nature of others (eg ethnicity, sexuality) have an important bearing on the sense I make of the world and the ways in which I am able to interact with and make sense of the world of others. The initial motivations for the research and the chosen methodological approach for example were informed by my classed, gendered, occupational identities and understandings of the world. Through the brief narrativization of my life history outlined in the previous section I attempt to mark out key events and relationships to offer a coherent account of myself (Butler, 2005). By making sense of myself through narration I recognised the methodological potential of using narrative methods in the research. In relation to narrative identity Ricoeur (1991:32) states:

'We never cease to interpret the narrative identity that constitutes us, in the light of the narratives proposed to us by our culture. In this sense our self-understanding presents the same features of traditionality as the understanding of a literary work...we learn to become narrator and the hero of our own story, without actually becoming the author of our own life'.

Therefore it can be argued that the production of storied narratives depends on positionality in terms of normative discourses of race, class, gender and so on. The narration of the self depends on specific cultural competencies and the experiences of certain practices that are 
classed, raced and gendered. Seeking empathy or reciprocity in research encounters (as some second wave feminist academics advocated) is thus more aligned to positivist objectives of identifying a recognisable and knowable truth. Here Ellsworth (1997) advocates counter-practices to empathy. So that rather than attempting to identify similarities with research participants the researcher becomes engaged in practices of queering, disidentifying, denaturalising, defamiliarising. Lather (2009:19) takes this further when she claims that overlooking differences for the sake of a comforting, self-justifying rush of identification through a will to understand the Other is a kind of violence 'an appropriation in the guise of an embrace'.

Embracing a rejection of empathy and recognising/celebrating difference between researcher and researched overcomes the impossible endeavour of seeking a match given the multiple and intersecting identities that we each have. As Francis and Archer (2005) argue by prioritising a match of some characteristics, that is, gender and/or age, and/or 'race' then messages are sent that some characteristics are more significant marks of commonality or difference than others. Whilst it has been recognised that there are advantages to 'matching' in terms of negotiating access to certain groups and promoting trusting relationships (Archer, 2002) the extent to which this translates into more equitable encounters during the research process remains contested. Furthermore Reay (1996) warns that similarity in social position between researcher and researched can hold the risk that findings become distorted because the researcher applies her lens to the data to subconsciously seek a 'fit' with her own experiences or identify with 'tropes of sameness' (see Byrne, 2003). The extremely diverse sample in my study would have made matching entirely impossible but more important than this is the recognition that interactions of gender, 'race', class and so on are not experienced in unitary or predictable ways (Archer, 2002).

\section{Preparing the ground: entering the field}

In preparing to enter the field I welcomed Diane Reay's invitation to reflect upon 'the difference your differences makes' (Reay, 1996; 443). I was filled with optimism and idealistic enthusiasm about the emancipatory potential of narrative methods; whilst at the same time troubled by the (invisible) power vested in me as the researcher who orchestrates and ultimately constructs research processes, encounters and outputs (Blumenreich, 2004).

By revisiting fieldwork notes I can trace the considerable anxiety I experienced about my 'presentation of self' to the nursery workers and managers. At each nursery I arranged to meet the entire staff and to introduce myself and the motivations for conducting the research and to provide details about the aims and scope of the study.

Following Bourdieu (1986) I understand class (and other marks of difference) to be inscribed on the self, and to be repeatedly signified through distinctions in lifestyle, food, aesthetics and so on. In meeting the staff at the nurseries I was engaged in deploying practical signifiers to locate 'the girls' in the broadest sense but also in relation to me. I offer an excerpt from my fieldnotes to demonstrate this process:

I was whisked into the largest room, shown to my seat, whereupon the manager left the room (to see to some other urgent matter). I sat for about five minutes and received confused stares, I proffered a few smiles but somehow it didn't seem appropriate to introduce myself. We were waiting for 'some of the girls' to return from going out to fetch food for the after-hours meeting. I felt strangely middleclass, the absence of 'bling' jewellery, tight fitting clothes and heavy make-up marked me as different. The youthfulness of the group was striking, although 
nursery managers often seem to refer to staff as 'the girls' it couldn't have been a more accurate description of this team. I would estimate the average age was 17-25. The girls embodied urban working-classness. They were rowdy and some were collectively singing along to a MP3 player. 'The girls' clearly attached significance to fashion and street culture, and a presentation of a certain version of femininity in which directness and practicality are valued. Eventually the 'missing girls' returned with the food - chips, burgers, chicken nuggets, coke - I found this interesting since the nursery promotes a nutrition policy to the middle-class families it serves; the importance of balanced-nutrition and positive association with food was emblazoned all around the nursery with notices about various food intolerances/preferences for the children. I interpreted this as a clear act of class rebellion.

I was invited to present my research study. I felt acutely aware of my accent, how I looked, what I was wearing, how I wore my hair, the terminology I was using. Despite claims to be a working-class feminist I felt conspicuously middle-class and extremely nerdy. Some girls who appeared to form an 'in-group' started to chat amongst themselves whilst I was explaining - I felt undermined, very uncomfortable and entirely unsure whether what I had said had been absorbed. As with the other nurseries I left the staff with the chance to reflect on whether or not they wanted to participate, and to relay their intention to me via the manager. I felt very despondent and unhopeful.

These reflections reveal that I was consumed by concerns about how far I could reasonably identify with this group of women. Despite gendered and classed motivations for undertaking the research, the distinctions between my lived experiences of class and gender were in many ways incongruous with those of this group of girls. The differences to which Reay (1997) refers were multiple; it is clear that I was engaged in processes of identification and disidentification with this group of young, urban, working-class women. Despite my acute self-awareness and concerns to manage the self in ways that would be nonthreatening, open, and transparent how research participants take this up is unpredictable and has unforeseen consequences. Despite despondency and negative expectations that none of 'the girls' would agree to participate in the research I was astonished to receive notification that eight 'girls' wanted to be interviewed.

Claims promoted in much feminist literature that the researcher occupies the ultimate position of power (Harding, 1987; Lather, 1988, Stanley and Wise, 1990) can be troubled by examples such as this. Second wave feminists (whose work was influential in shaping my approach at the outset of the study) stress the importance of creating non-hierarchical relationships with participants by processes of personal investment and disclosure and by appealing to commonalities and shared gendered (and classed) identities (Oakley, 1981; Skeggs, 1994). I was influenced by such worthy feminist ambitions but soon came to realise that such approaches can prove untenable and naive in the basic assumption that it is the researcher that holds the power in research encounters. Power constantly shifts and slides throughout research processes and as this example demonstrates this group of nursery workers held considerable power on whether or not to engage with the aims of the research, to attach any degree of importance to it, and ultimately, whether to participate.

\section{Outsider/intruder positioning}

Despite negotiating successful access to the nurseries and gaining the consent of a sample of nursery workers to interview, feelings of uncertainty and anxiety at my difference persisted 
throughout each day of fieldwork. A preoccupation with presentation of self persisted so that refusal to be interviewed was taken as a personal rebuttal. I spent many hours waiting to undertake prearranged interviews only to be left in the staff room or book corner with scant explanation or indication about whether I would collect data on that occasion. I converted such set backs into observational opportunities to record my thoughts and reflections about the daily interactions between staff; between staff and parents; between staff and other professionals; and between staff and children. Through this means I gathered rich and illuminating data to supplement that which I hoped to eventually gather through interviews. However, my avid note taking and (on some days) near-constant presence had unexpected consequences for how I came to understand myself in that context. I was caught between feeling voyeuristic; an encumbrance; overly studious to, at other times, feeling more authentic especially when I was invited to become 'one of the girls' by participating in activities, such as putting out the play equipment, helping with the cooking, setting up the Summer Fete and later in the year, preparing for a Christmas party. However, I was struck by how I was complicit in the co-construction of myself as in outsider/intruder, and the degree to which I was included rested to a large extent upon the participants' willingness to accept me. After several weeks of such ad hoc participation in daily life at the nursery, a participant remarked 'Well you're nothing if not persistent, come on then let's talk' and I was rewarded with a two-hour life history interview.

These reflections illustrate how participants are not passive but have at their disposal means and opportunity to direct and control the research situation in myriad ways. Numerous feminist commentators (eg Fine and Weis, 1996; Ramazanoglu with Holland, 2002; Stanley and Wise, 1990; Opie, 1992) have claimed that endeavouring for reciprocity in research situations can encourage less exploitative and less hierarchical practice. Whilst I concur that it is the responsibility of the researcher to acknowledge and make known the power relationships and potential costs of participation I would argue that it is possible for both the researched and the researcher to become discursively positioned in dominant and subordinate positions. I would suggest that on particular occasions like those described above, and through small acts of exercising subversive agency (such as repeatedly but inconsistently forgetting my name: some days I was Jenny, the next Janet, another day I became Joyce) I became discursively re-positioned; as insignificant and not as the 'expert' all-powerful researcher, which is often assumed in the literature.

I endeavoured to approach all aspects of the research sensitively and where possible to gauge/manage the effects of the research upon participants. It was my intention that the feminist emancipatory goals of my research should be translated and realised so that the nursery workers might feel equally passionate and committed. As illustrated, I made various attempts to translate this enthusiasm which on occasion unexpectedly resulted in ontological insecurity and a sense of vulnerability in situations where I had anticipated occupying a dominant position of power by virtue of a researcher identity (ref). As a means of preparing myself to conduct 'good femininist research' I undertook extensive reading of methodological texts yet this did little to alleviate the sense of uncertainty and self-doubt when in the field.

Drawing on the ideas of influential feminist scholars (Skeggs, 1994; Lather, 1988) I endeavoured to build trusting relationships based upon informed consent and to meaningfully engage the research participants in respectful ways. Whilst some embraced this, others overtly rejected my attempts. Such stage management of the research process appears to place power in the researcher's hands yet there are numerous examples where participants ceased power, through obstruction, silence, denial (Visweswaran 1996; Silin, 
2005). An initial interpretation could lead to the conclusion that I was failing in my attempts at reciprocal feminist emancipatory research. However, an alternative reading might suggest that such examples allowed space for the nursery workers to resist and subvert that which they constructed as part of middle-class normalising discursive practices (academic research), which seeks to construct them in particular ways for particular purposes.

Skeggs (1997) acknowledges that the power relations that come to characterise research relationships are multi-dimensional and not exclusively about the researcher holding the ultimate position of power. For feminist researchers the constant attention to the effects of the research upon the researched can, sometimes overstate the power held by the researcher and raises important questions about the fundamental purpose that research serves. Ultimately this raises questions about feminist preoccupations for reciprocity. Francis (2003) claims that concerns for rapport and respectful research relationships came from second-wave feminist assumptions that female researchers and respondents might bond over shared experience and revelations, and that consequently a valid, 'true' response could be produced. The post-structuralist position and theoretical framing of this research provides an explanation for the tensions I experienced. In effect, the purpose of my research and my motivations for managing the effects of the research processes on respondents did not stem from a desire to put them at ease so that they would reveal authentic truths about their lives and their identities. Rather the motivation for reflexivity and sensitivity comes from the need to maintain an awareness that material differences between researcher and researched (class, ethnicity, age) have important implications for the positions of power that we occupy. It remains important that (feminist) researchers ensure that respondents do not feel uncomfortable, intimidated or disempowered by the research process. Referring back to Ellsworth's (1997) advocacy of counter-practices to empathy; feminist researchers should not assume to 'know' their respondents, or present their articulations as coherent or true (re)presentations of selfhood.

\section{The emotional costs of narrative research: hearing and listening}

A central aspect of this research study was the use of life history interviews. The opening sections of this paper outline the rationale and appeal of narrative methods and their compatibility with the feminist agenda I was seeking to satisfy. At this juncture I want to review the emotional costs involved in the practical use of narrative research for both the researcher and the researched. Sieber and Stanley (1998) in debating the emotional risks involved in qualitative research focus on the social context and potential consequences to researchers and participants. The notion of intrusiveness and unsettling memories are frequently discussed as key emotional dangers of undertaking particular sorts of research (Sampson et al, 2008). Narrative life history methods can be taken to be both intrusive and about evoking memories through storied narratives. Therefore, I felt it important to exercise an ethic of care to both participants and self. I prepared myself by reading extensively about the method prior to entering the field (Andrews, 2000; Goodson \& Sikes, 2001; Middleton, 1992) and by alerting the participants to the potential challenges and costs of recounting their life history.

The rationale for using narrative method was so that participants could construct subjective experience through personal narrative, which might provide insights into their location within power structures and social contexts (Andrews, 2000). A further appeal of narrative method was the promise of opening up a dialogue where my subjectivity and storied narrative could find space in the generation of data. Middleton (1992) asserts that stories provide a starting point for active collaboration and views life history research as 'a process of deconstructing the discursive practices through which one's subjectivity has been 
constituted' (p.20). As with all research methods, issues of ethics and power are of key concern when accessing stories told.

The precise effect of narrative interviewing on either the participant, or myself remained unpredictable. Nevertheless, I sought to forewarn and prepare for the situation. A letter was sent to each nursery school manager, which was then circulated to all volunteers prior to interview. The letter included the following statement:

'I want to extend a note of warning at this stage - life history interviews can sometimes provoke strong emotions because of an event or relationship that has been painful in the person's past. This can sometimes be an unexpected outcome of being involved in research and I would just like to raise it now, and request that you mention it to all those who have volunteered - although I will reiterate it at the time of interview.'

Sampson et al (2008) highlight the inherent dangers for researchers of undertaking research that is likely to stimulate memories that might resonate with their own biographies. Given the feminist goals and the personal motivations I have outlined in this paper, the likelihood that the stories recounted might chime with my own biography were significant, although given the diversity of the sample and earlier reflections on the myriad ways in which classed, gendered, urban/rural identities are embodied I was also anticipating a degree of dissonance between the participants' and my own narrative. The note of caution extended to participants also acted to heighten personal anticipation of the possible consequences. In general the cautions offered to the nursery workers appeared not to dissuade them from participating; although through measures taken to manage the emotional interchange and potential discomfort I became complicit in the creation of a self-fulfilling prophecy for some. This was especially apparent in one of the nurseries where I initially struggled to arrange interviews. Many participants were reluctant and evasive, as evidenced by withdrawal from prearranged interviews at the last moment and by the order in which the interviews were organised. ${ }^{1}$ Although all other interviews were arranged with relative ease, my attempts to manage expectations of life history interviews caused a degree of anxiety and anticipation.

I draw on a specific example, recorded in my fieldnotes, of the decision-making processes around undertaking a life history interview with Debbie, a manager at one of the nurseries. I reiterated the aim of my study, stressed confidentiality, anonymity and gave a final health warning about life history methods, saying that Debbie need only tell me what she felt comfortable with, but that if sensitive topics came up then I was happy to listen, but that it wasn't a prerequisite. Debbie stated up front that she had lived a generally eventful life, but that she was committed to participating in the research - as she couldn't expect her staff to do something she wouldn't do herself, however uncomfortable it might be - this was also the reason she gave for going first.

The interview was very intense. Debbie became visibly upset when recounting memories of her childhood and in particular her father (working-class, violent, alcoholic, patriarch) and feelings of inadequacy and that others (namely her brothers) always come to rely on her in times of trouble - of which there were many. The interview lasted about two hours and Debbie was visibly shaken by the

\footnotetext{
${ }^{1}$ It was arranged for me to conduct interviews with a temporary member of staff and a parent volunteer in the first instance. A two-week period elapsed before I was able to interview any permanent members of staff. The entire fieldwork period at this nursery lasted seven months (compared to just three months each at the other nurseries in the study). I made countless visits to this nursery only to leave on many occasions with no interview data and an acute sense of dejection and powerlessness.
} 
experience - she stated that she had recounted events today that she had not told anyone. This made me feel privileged but apprehensive - that somehow the interview had crossed the boundary into therapy and I was not equipped to support or offer advice to her as that is beyond the realms of my role as researcher...I felt quite moved by Debbie's life history for the way it resonated with so much of my own life - particularly her parents volatile and unhealthy relationship, and how she had come to blame herself for her inability to resolve their problems. I too was feeling quite shell shocked and wondering whether life histories were entirely ethical or if I was the best person to carry them out given my own subject position.

These reflections reveal experiences of role conflict (Chatzifotiou, 2000). The similarities between counselling and life history interviews are well rehearsed (Goodson and Sikes, 2001). Both involve listening, reflection, probing to encourage further reflection, a nonjudgemental approach, and dealing with intimate aspects of life. However, applying a poststructuralist feminist interpretation to the notion of narrative research usefully opens up a debate about the inevitably partial and subjective ways in which stories are told and heard. Lather $(1988 ; 2009)$ troubles the authority that is credited to the testimonial voice, since it reflects an assumption that language is a transparent medium of truth and the speaking subject is stable and offering a coherent account. Narrative methods, story telling, giving an account of oneself - however it is framed, must be understood as a mutually constitutive activity that relies upon listening. Gray (2007) reminds us that listening is subjective and partial and that the identity of the listener, how we hear, and who we are listening to are crucially important to the feminist goal of 'giving voice'. Just as the processes involved in giving voice to storied narratives must be made transparent and exposed for the inherent partiality and subjectivity, so to must the effects of such 'mutually constitutive activity'. Further excerpts from my fieldnotes reveal the effects of hearing and listening to Debbie's voice in my research:

I returned the next morning just before 8am. Debbie looked really sheepish, almost embarrassed by the level of detail she had gone into yesterday. We greeted each other as the relative strangers that we are, but the dynamics between us were noticeably different...by imparting so much of her identity, insecurities and vulnerabilities I had a power today that I didn't have yesterday, because I now possessed knowledge about her, and despite what I felt were nods of recognition and empathy throughout the interview she knew no more about me today than she did yesterday. In some sense I felt I had been placed in a privileged position (which I could have anticipated) but which Debbie was entirely unaware of. She was almost apologetic when she escorted me to the spare room - she joked that I would need some therapy of my own once I had finished collecting my data - it didn't seem such a joke at the time!

Debbie's conflation of the research interview with 'therapy' is telling. Evidently the emotional risks and costs of intimate research methods are acute. As Foucault (1978) warns, once disclosed in public arenas, personal testimonies are available for expert inspection and can be used to support the same sets of circumstances that the declaration is understood to purge the 'confessor' from. Therefore, who does the listening, how the narratives are interpreted and taken up is crucially important. Foucault goes on to state that where such testimonials are subsumed into existing instruments of power social transformation is likely to be limited.

I hope to have demonstrated that post-structuralist feminist commitments to troubling the taken-for-granted, questioning the obvious, and constant re-evaluation of the ways in which 
research can achieve its emancipatory potential, is messy and carries a considerable emotional cost to both researcher and researched. It is naïve to assume what the effects of research might be or to over state the role of the researcher in creating certain effects or mitigating them through careful stage management. Taking the example of Debbie once more, I wrestled with whether (and in what ways) I should seek to address the consequences of the narrative interview. Since she likened it to therapy, I feared that boundaries had been overstepped and I had placed her in an emotionally precarious position. However, as with the other examples cited in this paper, in attempts to predict and manage the effects of research in the name of good feminist practice, unpredictable and unintended consequences occur. Here is Debbie's comment:

"I think it has been a useful experience, and I think probably the first interview was probably the hardest, because obviously it is a life history interview and so you are going back over your life and looking at things that you had either hoped you'd forgotten or thought you'd buried, so it did bring up lots of issues. But also, for me personally I think it gave closure to something to me that, to get where I am at, the route that I took and that sort of thing. But I think the process of being part of the research is, two reasons I suppose I felt I had to do it: one that I volunteered the centre [the nursery school] so I had to model, or lead by example if you like for the staff team. But also it is important to look back on why you do things, not only in your practice but I suppose in everyday life really. So I think the experience has been good."

Debbie had used the interview as a form of therapy but it is evident that she did not expect a therapeutic relationship with me as researcher. In addition to providing rich data and valuable reflective and reflexive opportunities to me, the study also provided Debbie with an opportunity to reflect on her life history and the intersection of her multiple identities and what this meant for her professional practice (Goodfellow, 2004).

\section{Conclusion}

It remains important to acknowledge the influential contribution that feminist researchers have made to the development of educational research. As a consequence of the work of second wave feminists, research has become a more reflexive endeavour, more attention is paid to power relationships and responsibilities in research, and sensitivity to debates about knowledge (how it is created, endorsed or identified and by whom). The emphasis on reflexivity, the consideration of power within research relationships and the potential for harm to come to participants has been foregrounded in much feminist writing (Francis, 2001; 2002; Hey, 1997; 1999; Oakley, 1981; Skeggs; 1994). Meantime, post-strutural theorising has encouraged researchers to problematise and dismantle, and whilst this has been taken up in productive ways by numerous feminist scholars (Davies, 2000; Francis, 2005; Hey 1999; Walkerdine et al, 2001,) it has not been without tensions.

This paper has demonstrated the tensions I experienced in the practical application of a feminist agenda set against post-structuralist commitments to deconstruction. In shifting the emphasis, 'giving voice' becomes understood as a means of making space for counter narratives. That is not to claim that those narratives or insider discourses offer an authentic truth, rather through emancipatory and reflexive research processes space has been created for women to articulate a storied narrative that is culturally, historically and socially specific. If individuals are understood as constantly in process, never fixed, but rather constituted and reconstituted through discursive practices that they have assess to in their daily lives 
(Davies, 2000) then all that the feminist researcher can do is strive to present the complexity of lives and the fluidity of identity.

\section{References}

Alcoff, L.M. (2009) The problem of speaking for others. In A. Jackson and L. Mazzei ( eds) Voice in Qualitative Inquiry: challenging conventional, interpretative, and critical conceptions in qualitative research. London: Routledge, pp. 117-136.

Andrews, M. (2000) Narrative and life history: an introduction. In M. Andrews, S. D. Sclater, C. Squire, and A. Treacher (eds) Lines of Narrative: Psychosocial perspectives (Routledge Studies in Memory \& Narrative). London: Routledge.

Archer, L. (2002). 'It's easier that you're a girl and that you're Asian': interactions of 'race' and gender between researchers and participants', Feminist Review 72 (2): 108132.

Arnot, M. and Reay, D. (2007). A sociology of pedagogic voice: power, inequality and pupil consultation. Discourse: Studies in the cultural politics of education, 28(3): 311-325.

Barthes, R. (1990). The Pleasure of Text. (trans. R. Miller). Oxford: Blackwell.

Bourdieu, P. (1986). Distinction: A social critique of the judgement of taste. London: Routledge.

Blumenreich, M. (2004). Avoiding the pitfalls of conventional narrative research: using poststructural theory to guide the creation of narratives of children with HIV. Qualitative Research 4(1): 77-90.

Butler, J. (2005). Giving an Account of Oneself. New York: Fordham University Press.

Byrne, B. (2003). Reciting the self: narrative representations of the self in qualitative interviews. Feminist Theory. 4: 29-49.

Cannella, G.S. (1997) Deconstructing Early Childhood Education: Social justice and revolution, New York: Peter Lang.

Chatzifotiou, S. (2000) Conducting qualitative research on wife abuse: dealing with the issue of anxiety, Sociological Research Online, 5(2) URL (consulted August 2007): http://www.socresonline.org.uk/5/2/chatzifotiou.html

Colley, H. (2006) Learning to labour with feeling: class, gender and emotion in childcare education and training, Contemporary Issues in Early Childhood, 7 (1): 15-29.

Davies, B. (2000) A Body of Writing: 1990-1999. Oxford: AltaMira Press.

Derrida, J. (1972) Positions. Chicago, IL: University of Chicago Press.

Diamond, I. and Quinby, L. (eds) (1988). Feminism and Foucault: Reflections on resistance. Boston: Northeastern University Press, pp. xi-xix.

Ellsworth, E. (1997). The uses of the sublime in teaching difference. Paper delivered at the annual meeting of the American Educational Research Association, Chicago: March 24-28.

Fine, M. and Weis, L. (1996) Writing the 'wrongs' of fieldwork: confronting our own research/writing dilemmas in urban ethnographies', Qualitative Inquiry, 2 (3): 25174.

Foucault, M. (1978) The History of Sexuality: Volumes I-III. New York: Pantheon.

Foucault, M. (1979) Discipline and Punish: The birth of the prison. Harmondsworth: Penguin.

Foucault, M. (1980) Power/Knowledge:Selected interviews and other writings 1972-1977. London: Routledge.

Foucault, M. (1983) The subject and power. Afterward to H. Dreyfus \& P. Rabinow (eds) Michel Foucault: Beyond structuralism and hermeneutics. Chicago: Chicago University Press, pp. 208-264.

Foucault, M. (1994). Power: Essential works of Foucault 1954-1984, Volume 3. J. D. Faubion (ed), R. Hurley (trans), London: Penguin. 
Francis, B. (2001) Commonality AND difference? Attempts to escape from theoretical dualisms in emancipatory research in education, International Studies in Sociology of Education, 11(2): 157-172.

Francis, B. (2002) Relativism, realism and feminism: an analysis of some theoretical tensions in research on gender identity, Journal of Gender Studies, 11 (1): 39-54.

Francis, B. (2003) The creation and dissemination of feminist research in education: facts and fictions? In C. Hughes (ed.) Disseminating Qualitative Research in Educational Settings: A critical introduction. Buckingham: Open University Press.

Francis, B. and Archer, L. (2005). British-Chinese pupils' and parents' constructions of the value of education, British Educational Research Journal, 30(1): 89-108.

Goodfellow, J. (2004) Documenting professional practice through the use of a professional portfolio, Early Years, 24(1): 63-74.

Goodson, I.F. and Sikes, P. (2001) Life History Research in Educational Settings: Learning from lives. Buckingham: Open University Press.

Gray, J. (2007). (Re)considering voice. Qualitative Social Work. 6(4): 411-430.

Guba, E. and Lincoln, Y. (2005) Paradigmatic controversies, contradictions, and emerging confluences. In N. Denzin \& Y. Lincoln (eds.) Handbook of Qualitative Research ( $3^{\text {rd }}$ Edition), pp. 191-215. Thousand Oaks, CA: Sage.

Harding, S. (1987). Feminism and Methodology, Milton Keynes: Open University Press.

Hey, V. (1997). Northern accent and southern comfort: subjectivity and social class. In P. Mahoney and C. Zmroczek.(eds) Class Matters: Working-class women's perspectives on social class. London: Taylor \& Francis, pp. 140-151.

Hey, V. (1999). Troubling the auto/biography of the questions: re/thinking rapport and the politics of social class in feminist participant observation. Paper presented at Gender and Education Second International Conference, University of Warwick, April.

Hughes, C. (2004). Class and other identifications in managerial careers: the case of the lemon dress, Gender, Work and Organization. 11(5): 526-543.

Lather, P. (1988) Feminist perspectives on empowering research methodologies, Women Studies International Forum, 11(6): 569-81.

Lather, P. (2007). Getting Lost: Feminist efforts towards a double(d) science. Albany, NY: SUNY Press.

Lather, P. (2009). Against empathy, voice and authenticity. In Voice in Qualitative Inquiry: challenging conventional, interpretative, and critical conceptions in qualitative research. London: Routledge, pp. 17-26.

Mazzei, L.A. \& Jackson, A. J. (2009) Introduction: The Limit of Voice in A. Jackson and L. Mazzei (eds) Voice in Qualitative Inquiry: Challenging conventional, interpretative, and critical conceptions in qualitative research. London: Routledge, pp. 1-13.

McNay, L. (1994) Foucault: A critical introduction. Cambridge: Polity Press.

Middleton, S. (1992). Feminist Pedagogy: A life-history approach. New York: Teachers College Press.

Oakley, A. (1981). Interviewing women: a contradiction in terms. In: H. Roberts (ed.) Doing Feminist Research. London: Routledge, pp. 30-61.

Opie, A. (1992) Qualitative research, appropriation of the 'other' and empowerment, Feminist Review, 40: 52-6.

Osgood, J. and Sharp, C. (2000). Developing Early Education and Childcare Services for the $21^{\text {st }}$ Century. Local Government Association, Research Report 12. Slough: NFER.

Parker, I. (ed.) (1998) Social Constructionism, Discourse and Realism. London: Sage.

Ramazanoglu, C. (ed.) (1994) Introduction. In Up Against Foucault: Explorations of some tensions between Foucault and feminism. London: Routledge. 
Ramazanoglu, C. with Holland, J. (2002) Feminist Methodology: Challenges and choices. London: Sage.

Reay, D. (1996) Dealing with difficult differences: reflexivity and social class in feminist research, Feminism and Psychology, 6(3): 443-456.

Reay, D. (1997) The success of failure or the failure of success? In P. Mahony and C. Zmroczek (eds) Class Matters: Working-class women's perspectives on social class. London: Taylor and Francis, pp. 17-29.

Riceour, P. (1991) Narrative identity (trans. D. Wood) in D. Wood (ed.) On Paul Riceour: Narrative and interpretation. London: Routledge.

Sampson, H., Bloor, M., and Fincham, B. (2008) A price worth paying? considering the 'cost' of reflexive research methods and the influence of feminist ways of doing', Sociology, 42(5): 919-933.

Sieber, J. E. and Stanley, B. (1998) Ethical and professional dimensions of socially sensitive research, American Psychologist. 43(10): 49-55.

Silin, J. (2005) Who can speak? Silence, voice and pedagogy. In N. Yelland (ed.) Critical Issues in Early Childhood Education. London: Routledge.

Skeggs (1994) Situating the production of feminist ethnography. In Researching Women's Lives from a Feminist Perspective. London: Taylor \& Francis.

Skeggs, B. (1997) Formations of Class and Gender. London: Sage.

Smith, S. (1993) Who's talking/ Who's talking Back? The subject of personal narrative, Signs. 18(21): 392-407.

Stanley, L. and Wise, S. (1990) Method, methodology and epistemology in feminist research processes. In L. Stanley (ed.) Feminist Praxis: Research, theory and epistemology. London: Sage.

Tamboukou, M. and Ball, S.J. (eds) (2003) Genealogy and ethnography: fruitful encounters or dangerous liaisons?' In Dangerous Encounters: Genealogy and ethnography (Eruptions, V. 17). London: Peter Lang.

Visweswaran, K. (1996). Fictions in Feminist Ethnography. Minneapolis, MM: University of Minnesota Press.

Walkerdine, V. (1990). Schoolgirl Fictions. London: Verso.

Walkerdine, V. (1997). Daddy's Girl: Young girls and popular culture. London: MacMillan.

Walkerdine, V., Lucey, H., and Melody, J. (2001). Growing Up Girl. London: Palgrave.

Weiler, K. and Middleton, S. (eds) (1999) Telling Women's Lives: Narrative inquiries in the history of women's education. Philadelphia: Open University Press. 